\title{
Overfishing and the disappearance of short-beaked common dolphins from western Greece
}

\author{
Giovanni Bearzi ${ }^{1, *}$, Stefano Agazzi ${ }^{1}$, Joan Gonzalvo ${ }^{1}$, Marina Costa ${ }^{1}$, \\ Silvia Bonizzoni ${ }^{1}$, Elena Politi ${ }^{1}$, Chiara Piroddi ${ }^{1,2}$, Randall R. Reeves ${ }^{3}$ \\ ${ }^{1}$ Tethys Research Institute, Viale G.B. Gadio 2, 20121 Milano, Italy \\ ${ }^{2}$ Fisheries Centre, University of British Columbia, 2202 Main Mall, Vancouver, British Columbia V6T 1Z4, Canada \\ ${ }^{3}$ Okapi Wildlife Associates, 27 Chandler Lane, Hudson, Québec J0P 1H0, Canada
}

\begin{abstract}
Once one of the most common cetaceans in the Mediterranean Sea, the short-beaked common dolphin has declined throughout the region since the 1960s and in 2003 this population was classified as Endangered in the International Union for Conservation of Nature (IUCN) Red List. Here, we document the species' precipitous decline in eastern Ionian Sea coastal waters across $13 \mathrm{yr}$. While 150 animals were present in the study area $\left(1050 \mathrm{~km}^{2}\right)$ in 1996, only 15 were observed in 2007 . A 12 mo assessment of fishing effort and catch, together with circumstantial evidence, suggests that the decline was caused largely by prey depletion resulting from overfishing. We analyzed the impacts of various fishing gear and estimated the degree of resource overlap between common dolphins and local fisheries. The total biomass removed annually by 308 fishing boats in the study area averaged $3571 \mathrm{t}$, while that consumed by common dolphins was $17 \mathrm{t}$. Resource overlap between common dolphins and fisheries - expressed as an average Pianka index of 0.5 - differed according to fishing gear, being higher for purse seiners $(0.7)$ and beach seiners $(0.4)$ and lower for bottom trawlers $(0.1)$, trammel boats $(0.2)$ and longliners (0.0). Only about 10 active purse seiners $(4 \%$ of the total active fishing fleet) were responsible for $33 \%$ of the biomass removal, and likely had the greatest impact on prey of common dolphins. This study indicates a high risk of local disappearance of common dolphins in the very near future, unless fishery management measures are implemented immediately. Purse seining should be the main management target.
\end{abstract}

KEY WORDS: Short-beaked common dolphin $\cdot$ Fishing $\cdot$ Prey depletion $\cdot$ Mediterranean Sea

\section{INTRODUCTION}

Once one of the most common cetacean species in the Mediterranean Sea, the short-beaked common dolphin Delphinus delphis has declined throughout the region since the 1960s (Bearzi et al. 2003). In 2003, the Mediterranean population was classified as Endangered in the International Union for Conservation of Nature (IUCN) Red List of Threatened Species, based on observed declines in the number of animals and extent of occurrence, as well as deterioration in the quality of habitat in large portions of the Mediterranean. In 2005, Mediterranean common dolphins were listed in Appendix I and II of the Convention on the Conservation of Migratory Species (Bonn Conven- tion, CMS). While it would be difficult to imagine a more favourable legal and international framework to support action in the region, conservation of common dolphins has remained 'on paper' (Bearzi 2007).

Although much of the Mediterranean basin has not been surveyed, there is clear evidence of population decline in portions where detailed studies have been conducted, e.g. the northern Adriatic Sea (Bearzi et al. 2004a) and the Gulf of Vera in southern Spain (Cañadas \& Hammond 2007). Here, we document the precipitous, ongoing decline of common dolphins in eastern Ionian Sea coastal waters across $13 \mathrm{yr}$. Also, we show that the decline suggested previously for a core area of $480 \mathrm{~km}^{2}$ between 1997 and 2004 (Bearzi et al. $2005,2006)$ has occurred over a wider area $\left(1050 \mathrm{~km}^{2}\right)$ 
and a longer time interval (1995 to 2007). Bearzi et al. (2006) discussed possible reasons for the observed declines of common dolphins and other megafauna that prey on epipelagic schooling fish and concluded that the most likely cause of the declines was prey depletion as a result of fishing pressure. Here, we provide quantitative data on fishing effort and landings in the Kalamos area, and we link these data to the ongoing local decline of common dolphins (and other megafauna). Our 12 mo assessment is consistent with the hypothesis that ecosystem damage has been caused by unsustainable fishing (Stergiou et al. 1997, 2007b).

Eastern Ionian Sea waters surrounding the island of Kalamos have been included by the Hellenic Ministry of the Environment in the Natura 2000 network ('Sites of Community Importance') under the 9243 EEC 'Habitats' Directive. In 2002 the Agreement on the Conservation of Cetaceans in the Black Sea, Mediterranean Sea and contiguous Atlantic area (ACCOBAMS), ratified by Greece, identified the area of Kalamos as one where pilot conservation and management actions should be developed and implemented immediately to preserve the habitat of common dolphins. In 2004, the Contracting Parties to ACCOBAMS 'welcomed' a Conservation Plan for Mediterranean common dolphins that identified Kalamos as an Area of Conservation Importance (Bearzi et al. 2004b).

The study presented here (1) indicates that there is a high risk that common dolphins will disappear from the Kalamos area in the very near future and (2) identifies fishery management measures that must be implemented immediately to prevent the further decline of common dolphins and deterioration of the local ecosystem.

\section{MATERIALS AND METHODS}

Study area. The study area, situated in eastern Ionian Sea coastal waters, includes the Ionian islands of Meganisi, Kalamos and Kastos and covers $1050 \mathrm{~km}^{2}$ of sea surface (Fig. 1). The sea floor is mostly 50 to $250 \mathrm{~m}$ deep, with rocky coasts and shallows covered by seagrass meadows. Waters are transparent (Secchi disk readings ranging between 10 and $30 \mathrm{~m}$ ) and oligotrophic (Gotsis-Skretas \& Ignatiades 2007), and river and agricultural runoff is insignificant (Pitta et al. 1998).
Survey and photo-identification effort. Surveys were conducted ad libitum from 4.7 to $5.8 \mathrm{~m}$ inflatable craft with rigid hulls powered by 50 to $100 \mathrm{HP} 4$-stroke outboard engines from 1995 to 2007 . The survey coverage totalled $34801 \mathrm{~km}$ on effort and 908 survey days, from May to September each year (Table 1). Surveys were conducted at speeds between 28 and $36 \mathrm{~km} \mathrm{~h}^{-1}$ under consistently good conditions: unimpaired visibility, sea state $\leq 1$ Douglas with no swell, and at least 2 experienced observers scanning the sea surface (eye elevation of approximately $2 \mathrm{~m}$ ). Such conditions characterize 'on effort' in Table 1.

Photo-identification of individuals. Colour photographs suitable for individual identification, based on long-term natural marks on the dolphins' dorsal fins (Würsig \& Würsig 1977, Neumann et al. 2002), were obtained on $356 \mathrm{~d}$. On each encounter with a group of dolphins, as many good photographs as possible were taken of all individuals present. Photo-identification was performed following Würsig \& Jefferson (1990), with cameras equipped with 70 to $200 \mathrm{~mm}$ f2.8 zoom lenses, using 100 ISO colour transparency film from 1995 to 2002, and digital photography from 2003 to 2007. Considering that digital photography substantially improves the effi-

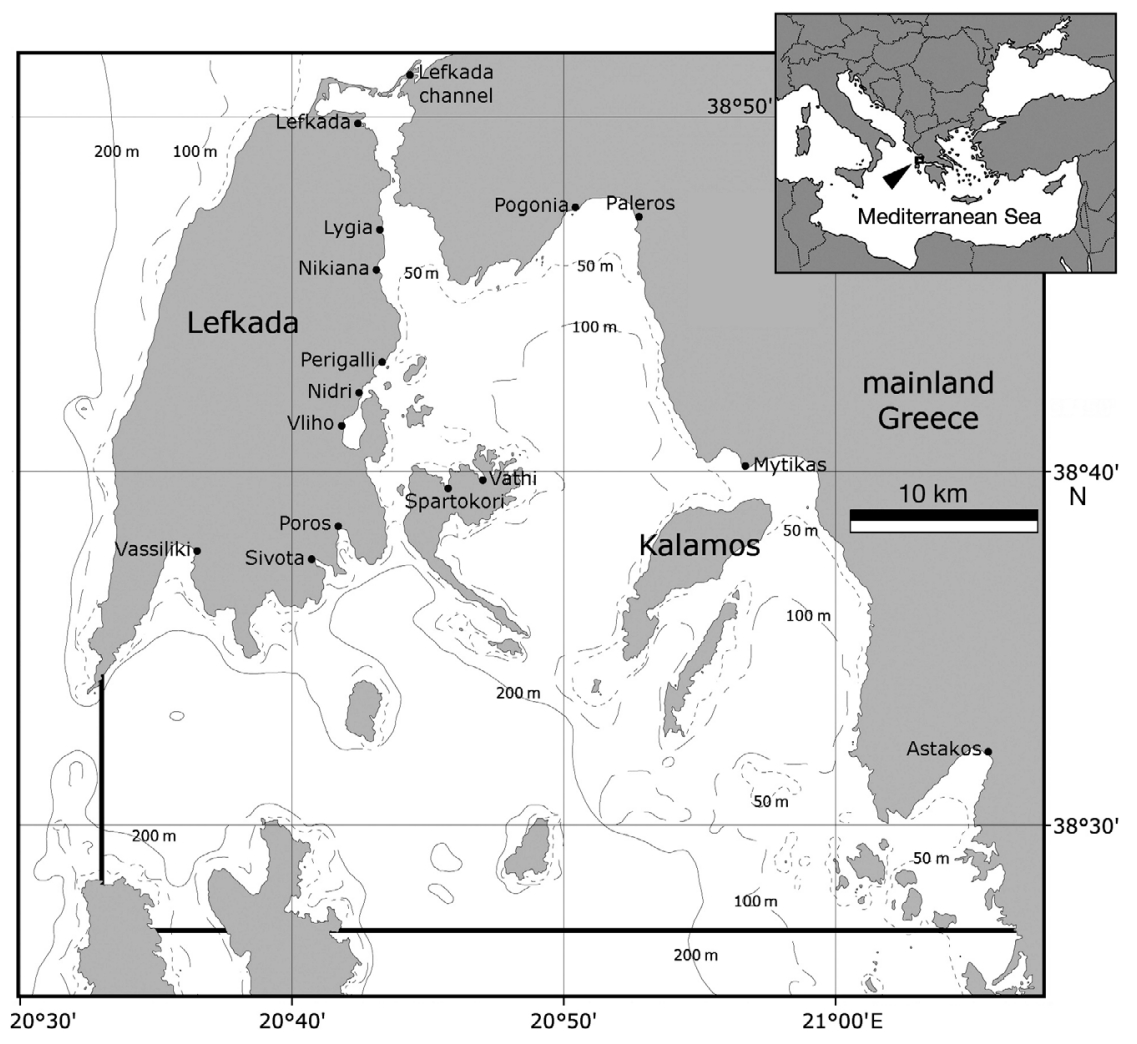

Fig. 1. Study area (delimited by bold line) with bathymetric contour lines and locations of fishing ports and other mooring/landing sites where local fishing fleets were monitored on a monthly basis from November 2006 to October 2007. The location of the study area relative to the eastern Mediterranean basin is shown in the inset 
Table 1. Number of daily surveys, common dolphin encounters and $\mathrm{km}$ surveyed 'on effort'

\begin{tabular}{|c|c|c|c|c|c|c|}
\hline Year & May & Jun & Jul & Aug & Sep & Subtotal \\
\hline \multicolumn{7}{|c|}{ Daily surveys: common dolphin encounters } \\
\hline 1995 & & & $6: 3$ & 13: 6 & 8: 4 & $27: 13$ \\
\hline 1996 & & 3: 2 & $17: 15$ & 22: 11 & $17: 6$ & 59: 34 \\
\hline 1997 & 15: 17 & 25: 18 & 20: 16 & $22: 14$ & 22: 17 & 104: 82 \\
\hline 1998 & $14: 11$ & $17: 10$ & 21: 18 & 20: 13 & $24: 17$ & 96: 69 \\
\hline 1999 & & $16: 7$ & 20: 15 & 22: 21 & $22: 8$ & 80: 51 \\
\hline 2000 & & $22: 13$ & 21: 12 & $24: 18$ & 21: 11 & 88: 54 \\
\hline 2001 & 1: 1 & 19: 16 & 18: 10 & $22: 7$ & $17: 2$ & $77: 36$ \\
\hline 2002 & $2: 0$ & $17: 10$ & 16: 3 & $23: 5$ & 11: 1 & 69: 19 \\
\hline 2003 & & 10: 6 & 11: 3 & 18: 4 & $20: 5$ & 59: 18 \\
\hline 2004 & $4: 0$ & 16: 2 & 11: 2 & 19: 3 & 11: 1 & 61: 8 \\
\hline 2005 & $3: 1$ & 15: 2 & 15: 3 & $17: 0$ & 16: 1 & $66: 7$ \\
\hline 2006 & 1: 0 & $14: 5$ & 14: 0 & 16: 0 & 18: 0 & $63: 5$ \\
\hline 2007 & & 13: 1 & 14: 1 & 17: 0 & 15: 2 & 59: 4 \\
\hline Total & 40: 30 & 187: 92 & 204: 101 & 255: 102 & $222: 75$ & 908: 400 \\
\hline \multicolumn{7}{|c|}{ Km surveyed 'on effort' } \\
\hline 1995 & & & 225 & 566 & 378 & 1169 \\
\hline 1996 & & 35 & 413 & 850 & 477 & 1774 \\
\hline 1997 & 231 & 608 & 543 & 432 & 576 & 2390 \\
\hline 1998 & 313 & 367 & 623 & 625 & 597 & 2525 \\
\hline 1999 & & 541 & 510 & 716 & 689 & 2456 \\
\hline 2000 & & 867 & 504 & 901 & 723 & 2995 \\
\hline 2001 & 1 & 465 & 541 & 962 & 500 & 2469 \\
\hline 2002 & 50 & 574 & 501 & 1075 & 463 & 2663 \\
\hline 2003 & & 1137 & 860 & 1359 & 936 & 4292 \\
\hline 2004 & 247 & 670 & 298 & 995 & 755 & 2965 \\
\hline 2005 & 155 & 445 & 514 & 940 & 883 & 2937 \\
\hline 2006 & 3 & 679 & 642 & 1079 & 918 & 3321 \\
\hline 2007 & & 566 & 887 & 949 & 444 & 2846 \\
\hline Total & 1000 & 6953 & 7061 & 11448 & 8339 & 34801 \\
\hline
\end{tabular}

ciency of individual dolphin identification (Markowitz et al. 2003), transparencies were scanned at high resolution and turned into digital images for consistency of evaluation and analysis. Photos were then cropped around the dorsal fin and visible part of the body and selected using consistent criteria (i.e. entire dorsal fin visible, fin perpendicular to camera, high sharpness and resolution, no water spray masking fin profile), based on recommendations provided by Read et al. (2003). Following such selection, the catalogue included 13319 transparencies and 4290 digital photos, totalling 17609 dorsal fin photos. These images were then matched, and the identified animals were included in a database. Only individuals with distinctive dorsal fin profiles, bearing marks suitable for reliable long-term identification from either side of the fin, were used for mark-recapture analyses. The characteristic white patch present on both sides of the fin of some animals could be used to confirm a match (Neumann et al. 2002, Bearzi et al. 2005) but not as a distinctive feature. Individuals with a single tiny nick or no nick on the dorsal fin's trailing edge, and individuals judged to be recognizable only based on dorsal fin shape and/or temporary scars were not used in the analyses, as their inclusion could result in borderline or incorrect matches and thus violate one or more mark-recapture assumptions. Patterns of site fidelity implied by photo-identification data (Fig. 2, where information from 1993 and1994 is also shown) and individual movements indicated by recordings of boat position (used as a proxy for dolphin position) at 6 min intervals during photo-identification follows (Fig. 3), assisted in the selection of the most appropriate model for markrecapture analyses.

Mark-recapture analyses. Markrecapture methods rely on the number of animals marked and their proportion in subsequent samples to estimate population parameters, including abundance (Seber 1982). Since the 1980s these methods have been used widely to estimate abundance of certain cetacean species based on photographic records of naturally marked individuals (Hammond 1990, Hammond et al. 1990, Wilson et al. 1999). Pollock's robust design (Pollock 1982) with Huggins estimator has been the preferred model. Previous work in the Kalamos area showed that this population of common dolphins could be regarded as open among years and closed within each annual sampling interval of 3 to 5 mo (Table 1), based on a high degree of site fidelity, individual movement patterns, and low rates of immigration (Bearzi et al. 2005). The programme Mark 4.3 (http://www.warnercnr.colostate.edu/ gwhite/mark/ mark.htm) was used for mark-recapture abundance estimation.

Monitoring fishing effort and landings. Prior to this study it had been difficult to document fishing pressure in the study area due to (1) poor reliability of the landing data (Watson \& Pauly 2001) - a well-known problem in the wider Mediterranean and in the Hellenic Seas in particular (Stergiou et al. 1997, 1998, Briand 2000) - and (2) the fact that local fishermen often deliberately misreport their catches with the intention of reducing taxation or avoiding stricter regulations (Bearzi et al. 2006). Estimation of biomass removal is essential to assess the impact of fisheries (Pitcher et al. 2002). As reliable data on fishing effort and fishery landings were unavailable, we incorporated in our dolphin study a monitoring component aimed at obtaining direct information on fishing within the study area. 


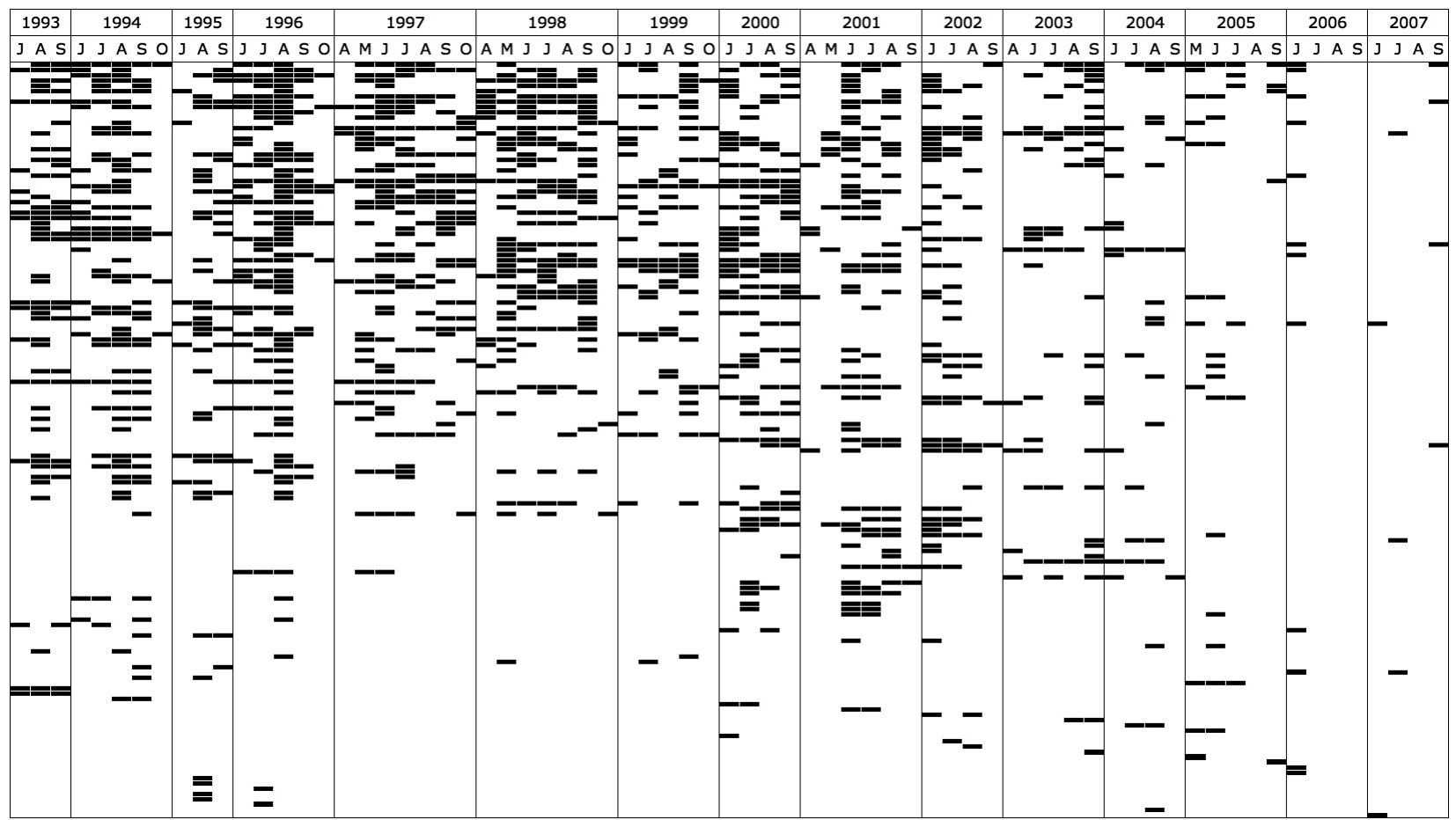

Fig. 2. Pattern of site fidelity by year and month for 143 common dolphins photo-identified in the study area between 1993 and 2007. Each row represents the sighting history of 1 individual

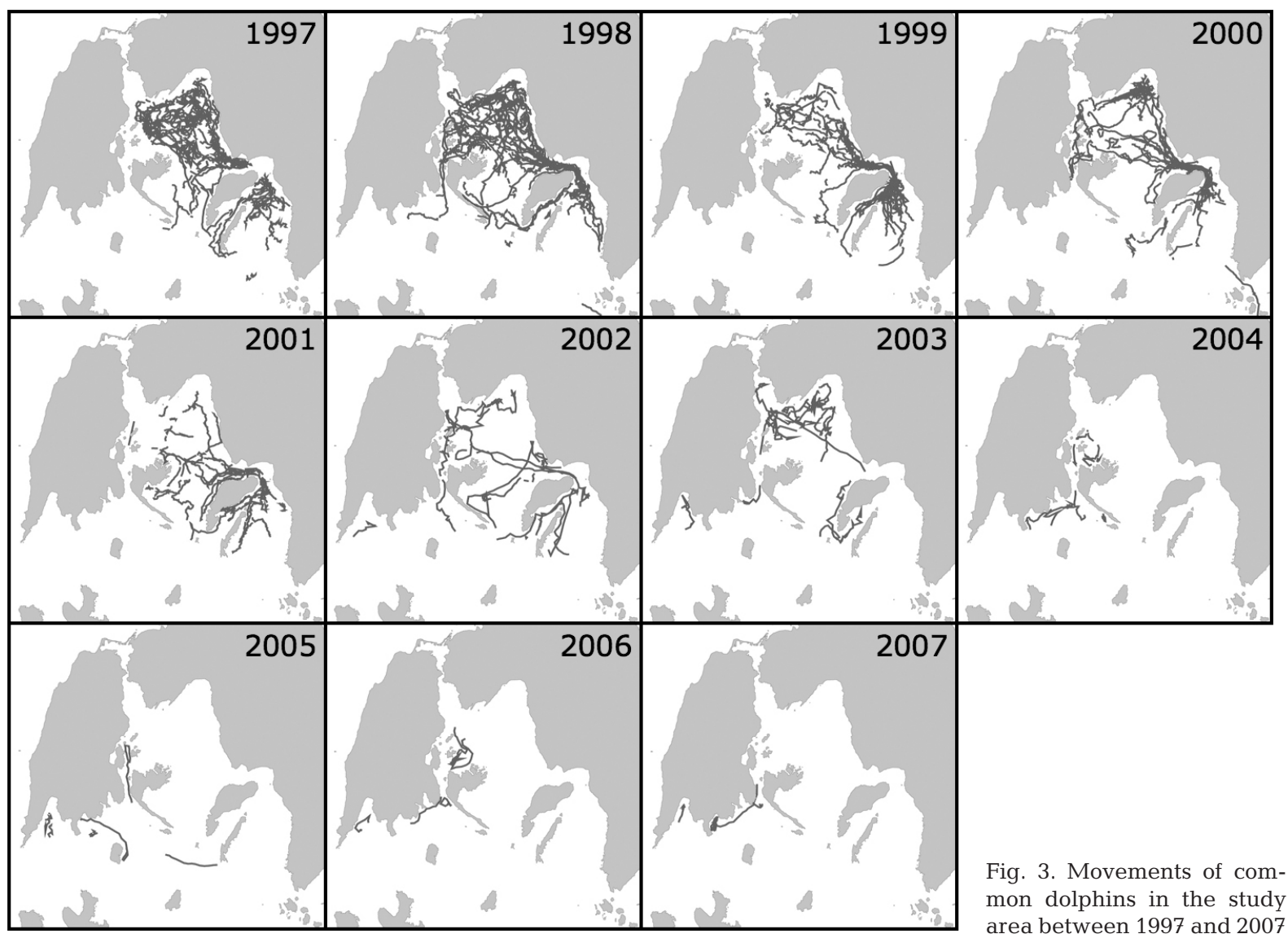


In November 2006, we started a programme to monitor the local fishing fleet in all 16 ports and other mooring/landing sites (Fig. 1). All sites were monitored once per month on days of bad sea state conditions and/or on Sundays, i.e. on days with a relatively high probability that the whole fishing fleet would be moored or in port. A total of 324 fishing boats were catalogued. Classification of fishing boats and gear was based on Nedelec \& Prado (1990). The activity status of each boat was recorded visually every month based on fishing gear on board or near the boat's mooring place, fishermen working on board, boat conditions, and direct inquiries. The local fishing fleet-i.e. the boats recorded as active in any given month during the study period-included 12 purse seiners (of which 11 were 15 to $25 \mathrm{~m}$ and 1 was $12 \mathrm{~m}$ long), 24 beach seiners of 8 to $12 \mathrm{~m}, 9$ bottom trawlers of 20 to $25 \mathrm{~m}, 50$ longliners ( 29 of 4 to $7 \mathrm{~m}$ and 21 of 7 to $10 \mathrm{~m}$ ), and 213 trammel boats (98 of 4 to $7 \mathrm{~m}$ and 115 of 7 to $12 \mathrm{~m}$ ). Boats shorter than $4 \mathrm{~m}$ were not considered, as their impact was assumed negligible. For the same reason a total of 16 boats 4 to $7 \mathrm{~m}$ long equipped with gas-powered lamps and tridents/harpoons were also excluded from the analyses. Some boats had multiple gears and switched from one fishing method to another depending on seasonal closures (Kapantagakis 2007). For instance, most beach seiners operated as trammel boats during months of beach seining closure. Therefore, active boats were classified according to the gear used in each month of sampling (e.g. a boat could be scored as a purse seiner in September and as a bottom trawler in October, depending on the gear used during those months).

Landings of purse seiners, beach seiners and bottom trawlers were monitored between November 2006 and October 2007. A total of 26 landings were recorded for purse seiners $\left(2.9 \pm 1.9 \mathrm{mo}^{-1}\right.$, mean $\left.\pm \mathrm{SD}\right), 14$ for beach seiners $\left(2.3 \pm 3.78 \mathrm{mo}^{-1}\right)$, and 16 for bottom trawlers $\left(2.0 \pm 1.31 \mathrm{mo}^{-1}\right)$. Total catch by species was recorded visually by trained researchers based on the number of full boxes landed (boxes were routinely divided by species before landing). Full boxes were estimated to average $10 \mathrm{~kg}$ irrespective of species (an assumption routinely used for market purposes at landing sites, confirmed by direct observations). Days of activity per month per boat for purse seiners, beach seiners and bottom trawlers were based on Kapantagakis et al. (2001), also taking into account periods of seasonal fishing closure. Average catch for trammel boats and longliners was estimated as $3.42 \mathrm{t} \mathrm{yr}^{-1}$ for boats 4 to $7 \mathrm{~m}$ long, and $6.31 \mathrm{t} \mathrm{yr}^{-1}$ for boats 8 to $11 \mathrm{~m}$ long (Stergiou et al. 2007c). Percentage catch contribution of the most abundant species for longliners and trammel boats operating in the Ionian Sea was based on Stergiou et al. (2007a). Discard rates were assumed to be $14 \%$ for purse seiners (Tsimenides et al. 1995-a value reported as likely to be an underestimate), $28 \%$ for beach seiners (Stergiou et al. 1996), 39\% for bottom trawlers (Machias et al. 2001) and 9.8\% for netters and longliners (Stergiou et al. 2002, Tzanatos et al. 2007). Biomass removed annually by fisheries - calculated separately according to fishing gear-was the product of average daily catch per boat, days of activity per month, number of boats recorded as active in each month of sampling, and months of fishing activity.

Resource overlap. To assess the similarity of biomass composition between common dolphin prey and fishery catches, we used Pianka's niche overlap index (a measure of resource overlap between 2 species; Pianka 1973, Pusineri et al. 2004):

$$
\alpha=\frac{\sum_{i} P_{i j} \times P_{i k}}{\sqrt{\sum_{i}\left(P_{i j}\right)^{2}} \times \sqrt{\sum_{i}\left(P_{i k}\right)^{2}}}
$$

where P $i j$ is the percentage of prey item $i$ of predator $j$, and Pik is the percentage of prey item $i$ of predator $k$. The index ranges between 0 and 1, and the similarity is higher the closer the index is to 1 .

While the precise diet composition of common dolphins in the study area is not known, diet preferences were inferred from (1) stomach contents of dead animals in the study area (Bearzi 2000) and in neritic habitat elsewhere (reviewed in Bearzi et al. 2003, Cañadas 2006), (2) observations of common dolphin feeding behaviour and diving patterns in the study area (Bearzi et al. 2005), (3) direct observations of feeding in neritic Mediterranean waters (Mussi \& Miragliuolo 2003, Cañadas 2006), and (4) analysis of fish scales sampled during surface feeding by common dolphins in the study area (Agazzi et al. 2004, Bearzi et al. 2006). Based on this information, we assumed an average diet to be composed of $80 \%$ Clupeidae and Engraulidae, 10\% Belonidae, Gadidae and small Carangidae, $5 \%$ Loliginidae, and $5 \%$ other families (Table 2). Average daily food consumption was estimated as $4.2 \mathrm{~kg}$ animal ${ }^{-1}$ using IB $=0.123 \mathrm{M}^{0.8}$ (Innes et al. 1987), where IB is the ingested biomass $\left(\mathrm{kg} \mathrm{d}^{-1}\right)$ and $\mathrm{M}$ the body mass in $\mathrm{kg}$. Body mass of common dolphins in the central Mediterranean averages $82.5 \mathrm{~kg}$ according to Cagnolaro et al. (1983). The body mass of juveniles was estimated as $50 \%$ of adult mass; nursing calves were not considered.

\section{RESULTS}

\section{Population trends}

Mark-recapture estimates showed that common dolphin numbers declined significantly and almost steadily between 1995 and 2007 (Fig. 4). No mark- 
Table 2. Estimated percentage composition of catches by fishing gear and inferred diet composition of local common dolphins (see 'Resource overlap' section in 'Materials and methods')

\begin{tabular}{|lcccccc|}
\hline & $\begin{array}{c}\text { Beach } \\
\text { seiners }\end{array}$ & $\begin{array}{c}\text { Purse } \\
\text { seiners }\end{array}$ & $\begin{array}{c}\text { Bottom } \\
\text { trawlers }\end{array}$ & Trammel & $\begin{array}{c}\text { Longliners } \\
\text { Common } \\
\text { dolphins }\end{array}$ \\
\hline Clupeidae, Engraulidae & 26 & 34 & 0 & 13 & 0 & 80 \\
Belonidae, Gadidae, small Carangidae & 0 & 26 & 17 & 0 & 0 & 10 \\
Loliginidae & 4 & 2 & 15 & 0 & 0 & 5 \\
Large Carangidae, all other Families & 70 & 38 & 68 & 87 & 100 & 5 \\
\hline
\end{tabular}

recapture estimates could be obtained in 2006 (5 encounters) and 2007 (4 encounters) due to insufficient recapture events in different months. However, owing to the small group sizes and small number of encounters, all animals sighted during those years were photo-identified. There were 12 marked animals in 2006 and 9 in 2007 (Fig. 4).

As mark-recapture estimates relied on natural markings to identify individuals, they refer exclusively to the population of marked animals. To include the unmarked portion and estimate total abundance, the proportion of unmarked individuals (which also included subadult classes) was computed based on the number of photographs of marked and unmarked dorsal fins obtained daily (Williams et al. 1993, Bearzi et al. 2008). Based on 1858 high-quality dorsal fin photos taken in 1997 (the year with greatest photoidentification effort), the mean proportion of unmarked animals in the population was $0.44(95 \% \mathrm{CI}=0.382$ to 0.494, $\mathrm{n}=74$ ). By adding this mean proportion of

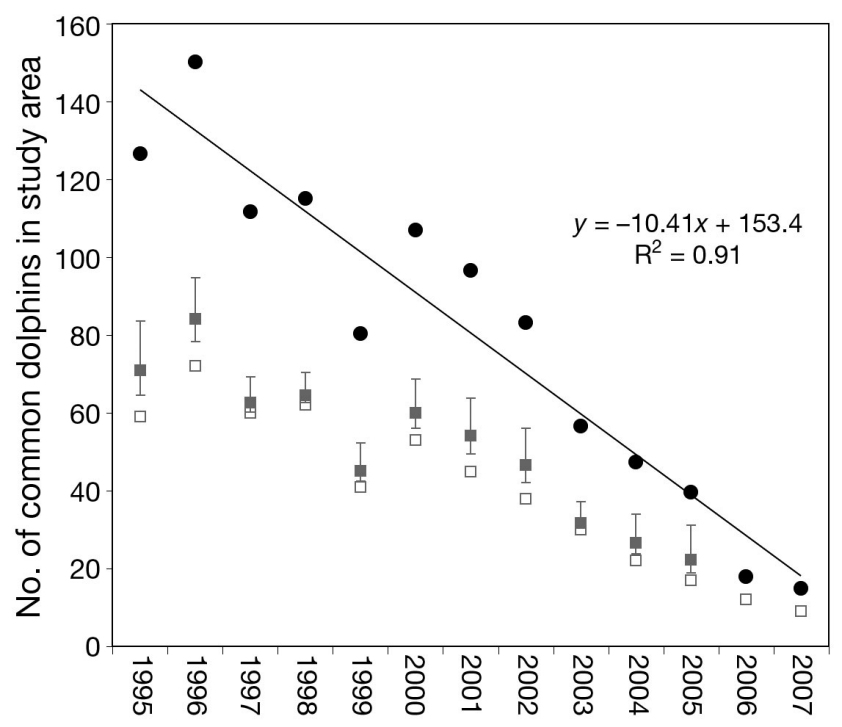

Fig. 4. Number of common dolphins in the study area between 1995 and 2007, estimated through photographic mark-recapture. $\square$ : total number of marked animals photoidentified; $\square$ : mark-recapture estimates; $\bullet$ : total population estimates (marked and unmarked animals) unmarked individuals to the mark-recapture estimate, we obtained estimates of total population size (Fig. 4).

Even though mark-recapture analyses were precluded in 2006 and 2007 by insufficient recaptures in those years, encounters were so few (Table 1), groups so small (range 2 to 9), and photo-identification effort so extensive that we had confidence in our ability to count and photograph all individuals present during the sightings. Direct counts of total animals photographed (18 individuals in 2006, 15 in 2007) were consistent with values obtained by adding the estimated unmarked animals to the number of marked animals (21 individuals in 2006, 16 in 2007), but field counts appeared to be the most accurate and were therefore used to complement information obtained through mark-recapture (Fig. 4).

The observed patterns of site fidelity (Fig. 2) and dolphin movement (Fig. 3) suggest that the decline indicated by the mark-recapture analysis applies to the entire local population of common dolphins.

\section{Impact of fishing and resource overlap}

Landings by purse seiners averaged $706.2 \mathrm{~kg}$ (SD = $967.91, \mathrm{n}=26$, range 0 to 4030 ). Species landed were predominantly horse mackerel Trachurus trachurus (26.2\% of the total catch), European pilchard Sardina pilchardus (23.1\%), bogue Boops boops (15.8\%), European mackerel Scomber scombrus (11.2\%), round sardinella Sardinella aurita (10.6\%; sometimes discarded before or during landing operations due to their low market value), picarel Spicara smaris $(7.5 \%)$, Atlantic bonito Sarda sarda (1.9\%), European squid Loligo vulgaris $(1.7 \%)$, European barracuda Sphyraena sphyraena $(1.0 \%)$ and skipjack tuna Katsuwonus pelamis (0.8\%). Landings by beach seiners averaged $125.6 \mathrm{~kg}$ ( $\mathrm{SD}=101.55, \mathrm{n}=14$, range 29 to 410). Species landed were predominantly picarel (56.1\%), European pilchard $(26.5 \%)$, bogue $(6.83 \%)$, European squid $(3.58 \%)$, European barracuda $(1.8 \%)$, striped red mullet Mullus surmuletus (1.3\%), greater amberjack Seriola dumerili $(0.9 \%)$, European mackerel $(0.6 \%)$ and annular seabream Diplodus annularis (0.6\%). Other 
species caught in small quantities (0.4 to $0.1 \%$ ) included gilthead seabream Sparus aurata, Octopus spp., salema Sarpa salpa, saddled seabream Oblada melanura, common pandora Pagellus erythrinus, European seabass Dicentrarchus labrax and common cuttlefish Sepia officinalis. Landings by bottom trawlers averaged $495.3 \mathrm{~kg}(\mathrm{SD}=350.40, \mathrm{n}=16$, range 195 to 1510$)$. Species landed included predominantly European hake Merluccius merluccius (36.6\%), horse mackerel $(17.0 \%)$, European squid (14.9\%), red shrimp Aristeus antennatus $(11.4 \%)$, striped red mullet $(7.7 \%)$, bogue (4.1\%), angler Lophius piscatorius $(1.7 \%)$, thornback ray Raja clavata (1.4\%), common pandora (1.1\%), silver scabbardfish Lepidopus caudatus (1.0\%), spottail mantis shrimp Squilla mantis (0.6\%), European seabass $(0.5 \%)$, and Octopus spp. (0.5\%). Other species caught in small quantities ( 0.4 to $0.1 \%$ ) included picarel, small-spotted catshark Scyliorhinus canicula, common cuttlefish, gilthead seabream, flathead mullet Mugil cephalus, and common sole Solea solea.

Estimates of the total biomass removed by the local fishing fleet between November 2006 and October 2007 and a comparison of the relative impact of different fishing boats are shown in Table 3, taking into account days of inactivity and discards (see 'Materials and methods'). The estimated total biomass removed by local fisheries was $3571 \mathrm{t}$. A Pianka's index of 0.5 reflects the likely present overall degree of resource overlap between common dolphins and fisheries in the study area (Table 2). Resource overlap differed according to fishing gear, being 0.7 for purse seiners, 0.4 for beach seiners, 0.1 for bottom trawlers, 0.2 for trammel

Table 3. Composition of the fishing fleet operating in the study area and biomass removed annually

\begin{tabular}{|c|c|c|c|c|c|}
\hline Boat kind & $\begin{array}{l}\text { Boat length } \\
(\mathrm{m})\end{array}$ & $\begin{array}{l}\text { Mean no. } \\
\text { of active } \\
\text { boats }\end{array}$ & $\begin{array}{l}\text { Active } \\
\text { months }\end{array}$ & $\begin{array}{c}\text { Annual } \\
\text { biomass } \\
\text { removal (t) }\end{array}$ & $\begin{array}{c}\% \text { of total } \\
\text { annual } \\
\text { biomass } \\
\text { removal }\end{array}$ \\
\hline \multirow[t]{3}{*}{ Purse seiner } & $15-25$ & 7.5 & 9.5 & 1166.5 & 32.7 \\
\hline & & 1.0 & 6 & & \\
\hline & 12 & 1.0 & 8 & & \\
\hline \multirow[t]{2}{*}{ Beach seiner } & $8-12$ & 1.0 & 4 & 528.7 & 14.8 \\
\hline & & 23.0 & 6 & & \\
\hline \multirow[t]{2}{*}{ Bottom trawler } & $20-25$ & 6.0 & 8 & 797.8 & 22.3 \\
\hline & & 1.0 & 6 & & \\
\hline \multirow[t]{6}{*}{ Trammel } & $4-5$ & 22.8 & 12 & 915.4 & 25.6 \\
\hline & $5-7$ & 49.4 & 12 & & \\
\hline & $7-10$ & 15.5 & 6 & & \\
\hline & & 83.9 & 12 & & \\
\hline & $10-12$ & 1.3 & 6 & & \\
\hline & & 2.2 & 12 & & \\
\hline \multirow[t]{3}{*}{ Longliner } & $<7$ & 15.3 & 12 & 162.7 & 4.6 \\
\hline & $7-9$ & 10.9 & 12 & & \\
\hline & $9-10$ & 4.5 & 12 & & \\
\hline
\end{tabular}

boats, and 0.0 for longliners (Fig. 5). The apparent lack of resource overlap between common dolphins and longliners is consistent with the catch composition observed in the Cyclades Islands (Stergiou et al. 2002) and in the Patraikos Gulf (Tzanatos et al. 2006). The biomass consumed by 15 common dolphins estimated to be present in the study area during the same time interval was about $17 \mathrm{t}$ (Fig. 5).

\section{DISCUSSION}

Once common and relatively abundant in the area of Kalamos, common dolphins have declined dramatically over the past decade. While approximately 150 animals used the study area in 1996, only 15 were observed in 2007. Tuna and swordfish also have declined (Bearzi et al. 2006). Large tuna, in particular, were commonly encountered in the early years of the study but were rarely seen after 2001. The decline of highorder marine predators that feed on epipelagic prey is consistent with the hypothesis that intensive exploitation of epipelagic fish stocks reduced the availability of key prey, making this coastal habitat less able to sustain populations of large predators (Bearzi et al. 2006). Other factors that might have played a significant role include unrecognized oceanic changes, tissue contamination by xenobiotic chemicals and incidental mortality in fishing gear, but only the last is likely to have been relevant. A local worker reported that 5 common dolphins with mutilations were found stranded near Paleros between December 2004 and April 2005. Of those, only 1 animal could be examined and based on mutilation of its tail flukes, it likely died in fishing gear (Bearzi 2006). No other reports were received of common dolphin bycatch during the entire 15 yr study (1993 to 2007) or during the 12 mo of fishery monitoring. Also, floating carcasses of common dolphins (possibly indicative of bycatch) were never observed over a total of $1163 \mathrm{~d}$ spent at sea within and around the study area since 1991, totalling $>67000 \mathrm{~km}$ of navigation. Bycatch is an important cause of mortality of common dolphins in some parts of the world (Tregenza et al. 1997, Tregenza \& Collet 1998, Julian \& Beeson 1998) and it may have contributed to the observed decline in common dolphins around Kalamos. However, we consider it unlikely that bycatch was the sole or even the main cause of the decline. 


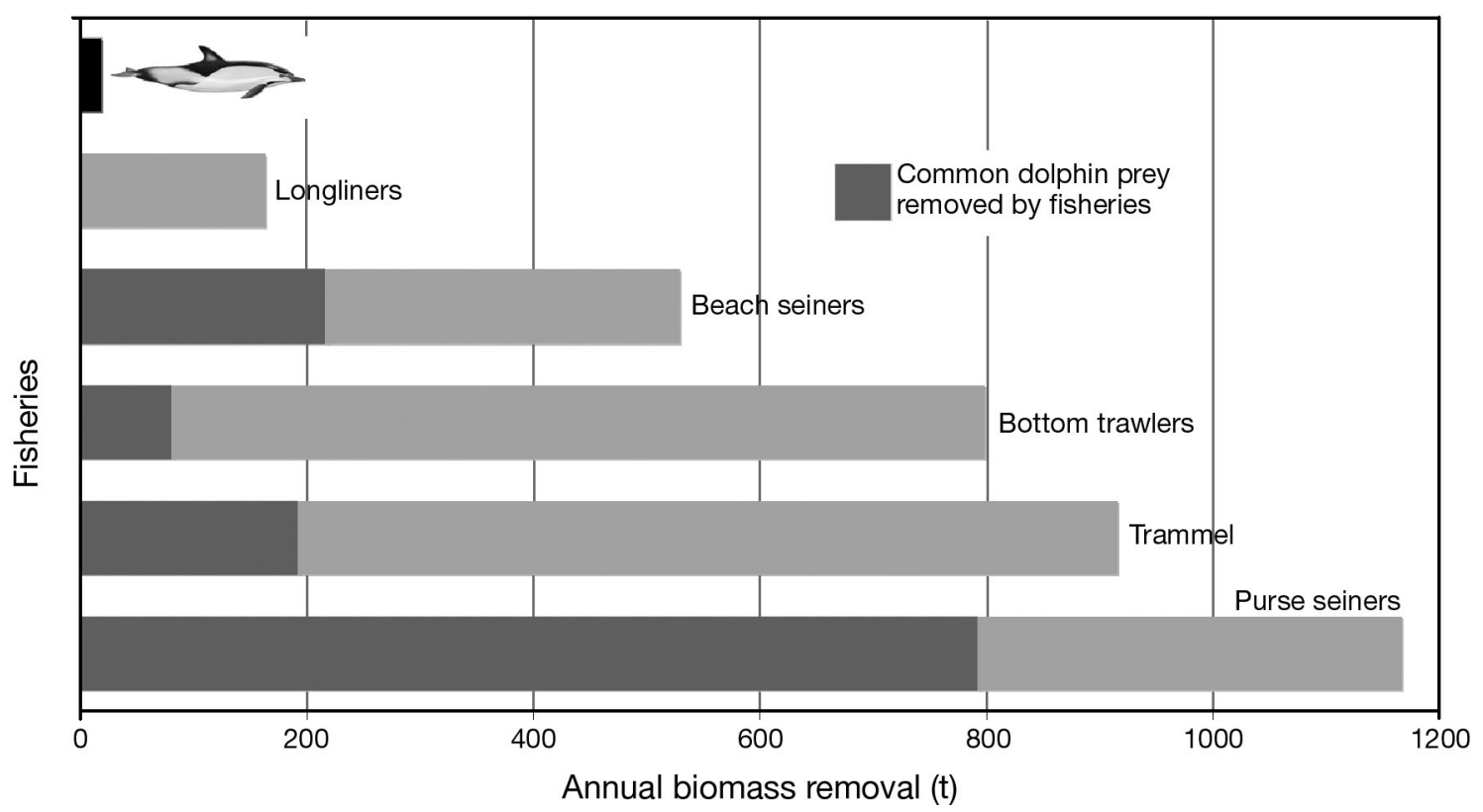

Fig. 5. Estimate of total biomass removed by common dolphins and fisheries in the last year of the study. The darker part of the fisheries bars shows removal of species representing key prey for common dolphins, as suggested by the index of resource overlap

As an alternative hypothesis, it is necessary to consider the possibility that the observed trends were a consequence of emigration or long-range movements. However, surveys outside the study area have provided no evidence to support the suggestion that common dolphins have shifted their distribution away from the Kalamos area (Bearzi et al. 2005). This area has been one of the few remaining pockets of high-density occurrence in the central and eastern Mediterranean, and there are few reports of common dolphins in surrounding areas. Dedicated cetacean surveys conducted by the Tethys Research Institute in the Ionian Sea between 1991 and 2007, covering more than $8200 \mathrm{~km}$ outside the Kalamos study area, produced no sightings of common dolphins. Notwithstanding substantial dedicated effort by several research groups, only 3 sightings have been reported to date from eastern Ionian Sea waters outside the study area (1 in each of 1992, 1995 and 1998; Angelici \& Marini 1992, Politi et al. 1992, Frantzis et al. 2003, Gannier 2005). Between 1999 and 2007, common dolphins were never seen north, west or south of the study area during cetacean surveys totalling tens of thousands of kilometres of dedicated effort and covering large portions of the eastern Ionian Sea, as well as waters west of the Peloponnese (Frantzis et al. 2003, Lacey et al. 2005, IFAW 2007, A. Frantzis pers. comm.). More generally, common dolphins appear to be rare in, or absent from, the adjacent central Mediterranean areas explored so far, including the Hellenic Trench, other neritic and pelagic portions of the Ionian Sea, and the Adriatic Sea
(Notarbartolo di Sciara et al. 1993, Bearzi et al. 2003, Frantzis et al. 2003, Gannier 2005, Lacey et al. 2005, IFAW 2007), the only exception being the inner Gulf of Corinth, where a few common dolphins remain (Frantzis \& Herzing 2002). Recent genetic evidence (Natoli et al. 2008) indicates a relatively high degree of differentiation among common dolphins in the Mediterranean and shows that common dolphins in the eastern part of the basin, including the Ionian Sea, are largely isolated from the western Mediterranean population.

Prey depletion caused by overfishing is thought to be one of the main reasons behind the overall decline of Mediterranean common dolphins (Bearzi et al. 2003, 2004a, Cañadas \& Hammond 2007). The declines in fish stocks and loss of marine biodiversity caused by fishing pressure are a growing concern worldwide (Pauly et al. 1998, 2002, Jackson et al. 2001, Pitcher 2001, Csirke 2005, Worm et al. 2006). Unsustainable fishing has been implicated in dramatic ecological changes in the Mediterranean Sea (Sala 2004), where it has caused the decline of many fish stocks (Caddy \& Griffiths 1990, De Walle et al. 1993, Stanners \& Bourdeau 1995, Caddy 1997, Garcia et al. 2005). Some of the Mediterranean fish stocks that have been overexploited include important prey species of common dolphins (Lleonart 2005).

While the impact of fishing remains to be assessed at the regional scale, there is ample and growing evidence of overfishing in the Hellenic Seas, including the eastern Ionian Sea. Around the island of Kalamos, 
total landings have decreased since the mid 1980s (Papaconstantinou et al. 1985, 1988, Papaconstantinou \& Stergiou 1995, Stergiou et al. 1997). European Commission (EC) figures indicate that catch per day of both demersal and pelagic resources has declined steeply in the Hellenic Ionian Sea over the last decade (EC 2004). In the eastern Ionian Sea, in particular, purse seine catch per day of both anchovies and sardines declined since the mid 1990s (EC 2004), especially for vessels larger than $15 \mathrm{~m}$, which account for the majority of the catch of small pelagic fish species (Stergiou et al. 2007b). The long-term increasing trends in Hellenic marine landings from 1964 to 1994, attributed to fleet modernization and geographic expansion of the fisheries over this period, have been followed since the mid 1990s by rapidly declining trends in landings and yields, suggesting that the fishing has been overly intense, i.e. unsustainable (Stergiou et al. 1997, 2007b, Stergiou 2005).

Overlap between dolphin prey species and fishery target species - as indicated by the Pianka's index does not prove direct competition (Briand 2004). However, it is reasonable to infer competitive effects when key prey becomes scarce and remains subject to heavy fishing pressure (Trites et al. 1997, Kaschner \& Pauly 2004, Pusineri et al. 2004). Around Kalamos, the potential for exploitative competition (Keddy 1989) between high-order predators such as common dolphins and local fisheries targeting their prey is apparent (Fig. 5). Overfishing and destructive fishing methods affect not only top predators, but also the fishery and in turn the fishing communities. Though it was not possible to quantify this aspect as part of the present study (cf. Saenz-Arroyo et al. 2005), local artisanal fishermen consistently lamented the declines in catches and reported to our research team that the local marine ecosystem had become less productive in recent decades.

The waters around Kalamos are an important spawning area for European pilchard (Somarakis et al. 2000, 2006a,b, Machias et al. 2007) and hake (Politou et al. 2006, Politou 2007), making this Natura 2000 Site of Community Importance a candidate for special protection based on EC Regulations for the sustainable exploitation of fishery resources in the Mediterranean (EC 2006). In addition to common dolphins, the area is home to species included in Annex II to the Habitats Directive, including a resident community of common bottlenose dolphins Tursiops truncatus and endangered species such as the Mediterranean monk seal Monachus monachus and the loggerhead sea turtle Caretta caretta.

In view of the evidence provided here, and considering the existing political and legal commitments to conserve cetaceans and preserve marine biodiversity (see 'Introduction') (Owen 2004), relevant local, na- tional and regional governmental bodies are obliged to take action to reduce fishing pressure and limit the use of fishing gears that can have unintended harmful effects on the marine environment. Fishery management measures are urgently needed to reduce current overexploitation and allow for the recovery of endangered marine megafauna. Such measures should include the following: (1) an immediate moratorium on purse seining, as advocated by the large local community of artisanal fishermen; (2) restrictions on bottom trawling; (3) strict enforcement and appropriate penalties for illegal fishing; and (4) full implementation of the Council Regulation 1967/2006, which also demands a ban on beach seining by May 31, 2010 (beach seining is considered harmful to fish stocks and habitats and has been banned in most EU Countries). As EC funding tools exist to compensate the affected fisheries, this may be a 'win-win' situation, where existing regulations can be effectively implemented to solve a specific conservation problem, with the added value of protecting marine biodiversity, ensuring continued ecosystem services, preserving artisanal fisheries, and bringing long-term benefits to human society.

Acknowledgements. This work was supported in part by a Pew Marine Conservation Fellowship (a programme of the Pew Institute for Ocean Science), by OceanCare, by The Whale and Dolphin Conservation Society, by the UNEP/CMS Agreement on the Conservation of Cetaceans of the Black Sea, Mediterranean Sea and Contiguous Atlantic Area, and by UNEP's Regional Activity Centre for Specially Protected Areas. Thanks to S. Bruno, S. Ferretti, A. Frantzis, A. Natoli, A. Petroselli and many other collaborators for contributing to field data collection and data analysis. Our gratitude also goes to all the volunteers who made this research possible through their financial support and help in the field. A. Frantzis, T. Lewis, D. Moutopoulos, G. Paximadis, E. Tryfon and A. I. Tsikliras contributed relevant information. Constructive comments were provided by C. M. Fortuna, G. Notarbartolo di Sciara, D. Pauly and 2 anonymous reviewers. R. Gramolini developed a dedicated tool to ease ArcView GIS analyses. The Milan Civic Aquarium and Hydrobiological Station provided logistical support. The work presented here was conducted under research permits issued by the Hellenic Ministry of Agriculture, General Directorate of Development \& Protection of Forests and Natural Environment, Directorate of Aesthetic Forests, Woodland and Hunting.

\section{LITERATURE CITED}

Agazzi S, Bearzi G, Politi E (2004) Short-beaked common dolphin prey species in the Eastern Ionian Sea: insight from fish scales sampled during surface foraging. Eur Res Cetaceans 15:351-353

Angelici FM, Marini L (1992) Sighting of Delphinus delphis (Cetacea, Odontoceti) in the Otranto Channel (southern Adriatic Sea and northern Ionian Sea). Hystrix 4:91-93

Bearzi G (2000) First report of a common dolphin (Delphinus delphis) death following penetration of a biopsy dart. J Cetacean Res Manag 2:217-221 
Bearzi G (2006) Preliminary report on the impact of fishing on common dolphins in the area of Kalamos, Greece (eastern Ionian Sea). Report 4th Meeting of ACCOBAMS Scientific Committee, Monaco, 5-8 November 2006. SC4/Inf09

Bearzi G (2007) Marine conservation on paper. Conserv Biol 21:1-3

- Bearzi G, Reeves RR, Notarbartolo di Sciara G, Politi E, Cañadas A, Frantzis A, Mussi B (2003) Ecology, status and conservation of short-beaked common dolphins (Delphinus delphis) in the Mediterranean Sea. Mammal Rev 33:224-252

Bearzi G, Holcer D, Notarbartolo di Sciara G (2004a) The role of historical dolphin takes and habitat degradation in shaping the present status of northern Adriatic cetaceans. Aquat Conserv 14:363-379

Bearzi G, Notarbartolo di Sciara G, Reeves RR, Cañadas A, Frantzis A (2004b) Conservation Plan for short-beaked common dolphins in the Mediterranean Sea. ACCOBAMS, Monaco. Available at: http://www. accobams.org/2006.php/documents/show/47

Bearzi G, Politi E, Agazzi S, Bruno S, Costa M, Bonizzoni S (2005) Occurrence and present status of coastal dolphins (Delphinus delphis and Tursiops truncatus) in the eastern Ionian Sea. Aquat Conserv 15:243-257

Bearzi G, Politi E, Agazzi S, Azzellino A (2006) Prey depletion caused by overfishing and the decline of marine megafauna in eastern Ionian Sea coastal waters (central Mediterranean). Biol Conserv 127:373-382

Bearzi G, Agazzi S, Bonizzoni S, Costa M, Azzellino A (2008) Dolphins in a bottle: abundance, residency patterns and conservation of common bottlenose dolphins Tursiops truncatus in the semi-closed eutrophic Amvrakikos Gulf, Greece. Aquat Conserv 18:130-146

Briand F (2000) Fishing down the Mediterranean food webs? CIESM Workshop Series. Kerkyra, 26-30 July 2000. CIESM, Monaco

Briand F (2004) Investigating the roles of cetaceans in marine ecosystems. CIESM Workshop Monographs 25

Caddy JF (1997) Mediterranean and Black Sea: FAO Statistical Area 37. FAO Marine Resources Service, Fishery Resources Division. FAO Fish Circ 920 FAO, Rome

Caddy JF, Griffiths RC (1990) Recent trends in the fisheries and environment in the General Fisheries Council for the Mediterranean (GFCM) area. Food Agricult Org Rome Studies Rev 63:1-71

Cagnolaro L, Di Natale A, Notarbartolo di Sciara G (1983) Cetacei. Guide per il riconoscimento delle specie animali delle acque lagunari e costiere. Consiglio Nazionale delle Ricerche AQ/1/224.9

Cañadas A (2006) Towards conservation of dolphins in the Alborán Sea. PhD thesis, Universidad Autónoma de Madrid

Cañadas A, Hammond PS (2008) Abundance and habitat preferences of short-beaked common dolphins (Delphinus delphis) in the South-western Mediterranean: implications for conservation. Endang Species Res 4:309-331

Csirke J (2005) Global production and state of marine fishery resources. In: Review of the state of world marine fishery resources. FAO Fisheries Technical Paper 457, FAO UN, Rome, p 1-9

De Walle FB, Nikolopoulou-Tamvakli M, Heinen WJ (1993) Environmental condition of the Mediterranean Sea: European Community Countries. Kluwer Academic Publishers, Dordrecht

EC (2004) European Union Mediterranean fisheries and exploited resources. Report of the Subgroup on the Mediterranean Sea (SGMED) of the Scientific, Technical and Economic Committee for Fisheries (STECF). SEC(2004)772

EC (2006) Corrigendum to Council Regulation (EC) No 1967/2006 of 21 December 2006 concerning management measures for the sustainable exploitation of fishery resources in the Mediterranean Sea, amending Regulation (EEC) No 2847/93 and repealing Regulation (EC) No 1626/94. Official J EU L 36:6-30

Frantzis A, Herzing DL (2002) Mixed-species associations of striped dolphins (Stenella coeruleoalba), short-beaked common dolphins (Delphinus delphis), and Risso's dolphins (Grampus griseus) in the Gulf of Corinth (Greece, Mediterranean Sea). Aquat Mamm 28:188-197

Frantzis A, Alexiadou P, Paximadis G, Politi E, Gannier A, Corsini-Foka M (2003) Current knowledge of the cetacean fauna of the Greek Seas. J Cetacean Res Manag 5:219-232

Gannier A (2005) Summer distribution and relative abundance of delphinids in the Mediterranean Sea. Rev EcolTerre Vie 60:223-238

Garcia SM, de Leiva Moreno I, Grainger R (2005) Global trends in the state of marine fishery resources 1974-2004. In: Review of the state of world marine fishery resources. FAO Fisheries Technical Paper 457. FAO UN. Rome, p 10-14

Gotsis-Skretas O, Ignatiades L (2007) The distribution of chlorophyll $a$ in the Aegean and Ionian Sea. In: Papaconstantinou C, Zenetos A, Vassilopoulou V, Tserpes G (eds) State of Hellenic fisheries. Hellenic Center Mar Res, Athens, p 24-27

Hammond PS (1990) Capturing whales on film: estimating cetacean population parameters from individual recognition data. Mammal Rev 20:17-22

Hammond PS, Mizroch SA, Donovan GP (1990) Individual recognition of cetaceans: use of photo-identification and other techniques to estimate population parameters. Rep Int Whal Commn, Special Issue 12

IFAW (International Fund for Animal Welfare) (2007) Some results of cetacean surveys between 2003 and 2007 in the Mediterranean's Western and Eastern basins. Report 3rd Meeting of the Parties to ACCOBAMS. Dubrovnik, 22-25 October 2007 MOP3/Inf16

Innes S, Lavigne DM, Earle WM, Kovacs KM (1987) Feeding rates of seals and whales. J Anim Ecol 56:115-130

Jackson JBC, Kirby MX, Berger WH, Bjorndal KA and others (2001) Historical overfishing and the recent collapse of coastal ecosystems. Science 293:629-638

Julian F, Beeson M (1998) Estimates of marine mammal, turtle, and seabird mortality for two California gillnet fisheries: 1990-95. Fish Bull (Wash DC) 96:271-284

Kapantagakis A (2007) Management and legislation in Hellenic fisheries. In: Papaconstantinou C, Zenetos A, Vassilopoulou V, Tserpes G (eds) State of Hellenic fisheries. Hellenic Center Mar Res, Athens, p 151-158

Kapantagakis A, Machias A, Stergiou KI, Somarakis S and others (2001) Patterns and propensities in Greek fishing effort and catches. Final Report of Project PAPIFEC, EUDG XIV, IMBC and Aristotle University, Thessaloniki

Kaschner K, Pauly D (2004) Competition between marine mammals and fisheries: food for thought. Humane Society, Washington, DC

Keddy PA (1989) Competition. Chapman \& Hall, London

Lacey C, Lewis T, Moscrop A (2005) Sightings made during visual surveys of the Mediterranean Sea in 2003 and 2004, including an unusual encounter with rough-toothed dolphins (Steno bredanensis) in the Ionian Sea. In: Evans PGH, Ridoux V (eds) Proc 19th Annu Conf Euro Cetacean Soc, La Rochelle, 2-7 April 2005 (on CD) 
Lleonart J (2005) Mediterranean and Black Sea. In: Review of the state of world marine fishery resources. FAO Fisheries Technical Paper 457. FAO UN, Rome, p 49-64

Machias A, Vassilopoulou V, Vatsos D, Bekas P, Kallianiotis A, Papaconstantinou C, Tsimenides N (2001) Bottom trawl discards in the northeastern Mediterranean Sea. Fish Res 53:181-195

Machias A, Giannoulaki M, Somarakis S, Siapatis A (2007) Small pelagics fish. In: Papaconstantinou C, Zenetos A, Vassilopoulou V, Tserpes G (eds) State of Hellenic fisheries. Hellenic Center Mar Res, Athens, p 192-207

Markowitz TM, Harling AD, Würsig B (2003) Digital photography improves efficiency of individual dolphin identification. Mar Mamm Sci 19:217-223

Mussi B, Miragliuolo A (2003) I cetacei della costa nord occidentale dell'isola d'Ischia (Canyon di Cuma). In: Gambi $\mathrm{MC}$, De Lauro M, Jannuzzi F (eds) Ambiente marino e costiero e territorio delle isole Flegree (Ischia, Procida e Vivara - Golfo di Napoli): risultati di uno studio multidisciplinare. Memorie dell'Accademia di Scienze Fisiche e Matematiche, Società Italiana di Scienze, Lettere e Arti in Napoli. Liguori Editore, Napoli, p 213-232

Natoli A, Cañadas A, Vaquero C, Politi E, Fernandez-Navarro P, Hoelzel AR (2008) Conservation genetics of the shortbeaked common dolphin (Delphinus delphis) in the Mediterranean Sea and in the eastern North Atlantic Ocean. Conserv Genet doi:10.1007/s10592-007-9481-1

Nedelec C, Prado J (1990) Definition and classification of fishing gear categories. FAO Fisheries Technical Paper 222 (Rev. I). FAO UN, Rome

Neumann DR, Leitenberger A, Orams MB (2002) Photo-identification of short-beaked common dolphins (Delphinus delphis) in north-east New Zealand: a photo-catalogue of recognisable individuals. New Zeal J Mar Freshw 36:593-604

Notarbartolo di Sciara G, Venturino MC, Zanardelli M, Bearzi G, Borsani FJ, Cavalloni B (1993) Cetaceans in the central Mediterranean Sea: distribution and sighting frequencies. Ital J Zool (Modena) 60:131-138

Owen D (2004) Legal instruments of relevance to the conservation of common dolphins in the Mediterranean Sea. In: Bearzi G, Notarbartolo di Sciara G, Reeves RR, Cañadas A, Frantzis A (eds) Conservation Plan for short-beaked common dolphins in the Mediterranean Sea. ACCOBAMS, Monaco, p 61-85. Available at: http:// www.accobams.org/2006.php/documents/show/47

Papaconstantinou C, Stergiou K (1995) Biology and fishery of hake, Merluccius merluccius L., 1758, in the eastern Mediterranean. In: Alheit J, Pitcher TJ (eds) Hake: fisheries products and markets. Fish and Fisheries Series 15. Chapman \& Hall, London, p 149-180

Papaconstantinou C, Caragitsou H, Panos T (1985) Preliminary utilization of trawl survey data for hake $(M$. merluccius) population dynamics from the Western Greek waters. FAO Fish Rep 345:87-92

Papaconstantinou C, Mytilineou C, Panos T (1988) Aspects of the life history and fishery of the red pandora, Pagellus erythrinus (Sparidae), off western Greece. Cybium 12: 267-280

Pauly D, Christensen V, Dalsgaard J, Froese R, Torres F Jr (1998) Fishing down marine food webs. Science 279: 860-863

Pauly D, Christensen V, Guénette S, Pitcher TJ, Sumaila UR, Walters CJ (2002) Towards sustainability in world fisheries. Nature 418:689-695

Pianka ER (1973) The structure of lizard communities. Annu Rev Ecol Syst 4:53-74
Pitcher TJ (2001) Fisheries managed to rebuild ecosystems? Reconstructing the past to salvage the future. Ecol Appl 11:601-617

Pitcher TJ, Watson R, Forrest R, Valtysson HP, Guenette S (2002) Estimating illegal and unreported catches from marine ecosystems: a basis for change. Fish Fish 3: 317-339

Pitta P, Tsapakis M, Zivanovic S, Karakassis I 1(1998) Seasonal variability of water column biogeochemistry in three coastal areas in the Ionian and Aegean Seas. Rap Commn Int Mer Médit 35:284-285

Politi E, Bearzi M, Notarbartolo di Sciara G, Cussino E, Gnone G (1992) Distribution and frequency of cetaceans in the waters adjacent to the Greek Ionian islands. Eur Res Cetaceans 6:75-78

Politou CY (2007) Current state of demersal fisheries resources. In: Papaconstantinou C, Zenetos A, Vassilopoulou V, Tserpes G (eds) State of Hellenic fisheries. Hellenic Center Mar Res, Athens, p 183-191

Politou CY, Chilari A, Dokos J, Kallianiotis A, Tserpes G, Peristeraki $P$ (2006) Identification of the nurseries of hake and deep-water pink shrimp in the Greek waters using trawl survey data. Working paper, STECF/SGMED-06-01 subgroup meeting on Sensitive and Essential Fish Habitats in the Mediterranean, Rome, 6-10 March 2006

Pollock KH (1982) A capture-recapture design robust to unequal probability of capture. J Wildl Manag 46:757-760

Pusineri C, Meynier L, Spitz J, Ridoux V (2004) Study of dietary overlap between small cetaceans and fisheries in the Bay of Biscay from stomach content analysis. In: Briand F (ed) Investigating the roles of cetaceans in marine ecosystems. CIESM Workshop Monograph 25. CIESM, Monaco, p 59-66

Read AJ, Urian KW, Wilson B, Waples DM (2003) Abundance of bottlenose dolphins in the bays, sounds and estuaries of North Carolina. Mar Mamm Sci 19:59-73

Saenz-Arroyo A, Roberts CM, Torre J, Carino-Olvera M, Enriquez-Andrade RR (2005) Rapidly shifting environmental baselines among fishers of the Gulf of California. P Roy Soc B-Biol Sci 272:1957-1962

Sala E (2004) The past and present topology and structure of Mediterranean subtidal rocky-shore food webs. Ecosystems (N Y, Print) 7:333-340

Seber GAF (1982) The estimation of animal abundance and related parameters, 2nd edn. MacMillan, New York

Somarakis S, Machias A, Koutsikopoulos C, Maraveya E, Giannoulaki M, Tsimenides N (2000) Distribution of anchovy and its spawning grounds off the central Aegean and Ionian Seas. Proc 6th Panhellenic Symp Oceanogr Fisheries 2:94-98 (in Greek)

Somarakis S, Ganias K, Siapatis A, Koutsikopoulos C, Machias A, Papaconstantinou C (2006a) Spawning habitat and daily egg production of sardine (Sardina pilchardus) in the eastern Mediterranean. Fish Oceanogr 15:281-292

Somarakis S, Tsianis DE, Machias A, Stergiou KI (2006b) An overview of biological data related to anchovy and sardine stocks in Greek waters. In: Palomares MLD, Stergiou KI, Pauly D (eds) Fishes in databases and ecosystems. Fisheries Centre Research Reports 14(4). Fisheries Centre, University of British Columbia, Vancouver, p 56-64

Stanners D, Bourdeau P (1995) Europe's environment: the Dobris Assessment. European Environment Agency, Copenhagen

Stergiou KI (2005) Fisheries impact on trophic levels: longterm trends in Hellenic waters. In: Papathanassiou E, Zenetos A (eds) State of the Hellenic marine environment. Hellenic Center Mar Res, Athens, p 326-329 
Stergiou KI, Petrakis G, Politou CY (1996) Small-scale fishery in the South Euboikos Gulf (Greece): species composition and gear competition. Fish Res 26:325-336

Stergiou KI, Christou ED, Georgopoulos D, Zenetos A, Souvermezoglou C (1997) The Hellenic seas: physics, chemistry, biology and fisheries. Oceanogr Mar Biol 35:415-538

Stergiou KI, Economou A, Papaconstantinou C, Tsimenides N, Kavadas S (1998) Estimates of discards in the Hellenic commercial trawl fishery. Rap Commn Int Expl Sci mer Méd 35:490-491

Stergiou KI, Moutopoulos DK, Erzini K (2002) Gill net and longlines fisheries in Cyclades waters (Aegean Sea): species composition and gear competition. Fish Res 57:25-37

Stergiou KI, Machias A, Somarakis S, Kapantagakis A (2007a) Multivariate analysis of fisheries catch per day in Greek waters. In: Zeller D, Pauly D (eds) Reconstruction of marine fisheries catches for key countries and regions (1950-2005). Fisheries Centre Research Reports Vol. 15(2). Fisheries Centre, University of British Columbia, Vancouver, p 139-148

Stergiou KI, Moutopoulos DK, Tsikliras AC (2007b) Spatial and temporal variability in Hellenic marine fisheries landings. In: Papaconstantinou C, Zenetos A, Vassilopoulou V, Tserpes G (eds) State of Hellenic fisheries. Hellenic Center Mar Res, Athens, p 141-150

Stergiou KI, Moutopoulos DK, Tsikliras AC, Papaconstantinou C (2007c) Hellenic marine fisheries: a general perspective from the National Statistical Service data. In: Papaconstantinou C, Zenetos A, Vassilopoulou V, Tserpes G (eds) State of Hellenic fisheries. Hellenic Center Mar Res, Athens, p 132-140

Tregenza NJC, Collet A (1998) Common dolphin Delphinus delphis bycatch in pelagic trawl and other fisheries in the northeast Atlantic. Rep Int Whal Commn 48:453-459

Tregenza NJC, Berrow SD, Hammond PS, Leaper R (1997) Common dolphin, Delphinus delphis L., bycatch in bottom

Editorial responsibility: Rebecca Lewison,

San Diego, California, USA set gillnets in the Celtic Sea. Rep int Whal Commn 47:835-839

Trites AW, Christensen V, Pauly D (1997) Competition between fisheries and marine mammals for prey and primary production in the Pacific Ocean. J NW Atlantic Fish Sci 22:173-187

Tsimenides N, Economou A, Stergiou KI, Papaconstantinou C, Walsh M, Bagicos G (1995) Estimates of discards in Hellenic commercial fisheries. Report MED92/018, Fishing News Publications, Athens

Tzanatos E, Somarakis S, Tserpes G, Koutsikopoulos C (2006) Identifying and classifying small-scale fisheries métiers in the Mediterranean: a case study in the Patraikos Gulf, Greece. Fish Res 81:158-168

Tzanatos E, Somarakis S, Tserpes G, Koutsikopoulos C (2007) Discarding practices in a Mediterranean small-scale fishing fleet (Patraikos Gulf, Greece). Fish Manag Ecol 14:277-285

Watson R, Pauly D (2001) Systematic distortions in world fishery catch trends. Nature 414:534-536

Williams JA, Dawson SM, Slooten E (1993) The abundance and distribution of bottlenosed dolphins (Tursiops truncatus) in Doubtful Sound, New Zealand. Can J Zool 71:2080-2088

Wilson B, Hammond PH, Thompson PM (1999) Estimating size and assessing trends in a coastal bottlenose dolphin population. Ecol Appl 9:288-300

Worm B, Barbier EB, Beaumont N, Duffy JE and others (2006) Impacts of biodiversity loss on ocean ecosystem services. Science 314:787-790

Würsig B, Jefferson TA (1990) Methods of photo-identification for small cetaceans. Rep Int Whaling Comm 12(Special Issue): $43-52$

> Würsig B, Würsig M (1977) The photographic determination of group size, composition, and stability of coastal porpoises (Tursiops truncatus). Science 198:755-756

Submitted: January 2, 2008; Accepted: May 1, 2008

Proofs received from author(s): June 25, 2008 